there is no end; and much study is a weariness of the flesh" - it seems justifiable to enquire into the purpose and function of the series in general and of this volume in particular.

Workers in any field of nervous system research will have recourse to original articles published in the several journals devoted to the appropriate disciplines. From tirne to time, experts gather together to hold a symposium on some particular topic. Although these symposia rarely provido now data, they are frequently productive of fertile new ideas-usually in direct proportion to the restriction of their terms of reference. Two superb rocent examples are the symposium on "Olfaction and Taste" and the CIBA symposium on "Touch Heat and Pain" (1966). A fow volumes in the "Progress in Brain Rosearch" sories may be classed in this category. The present volume most cortainly cannot. If the first four chapters are at least cohesive, two of thom are redundantprobably through no fault of their authors. The summer school from which this book originates is supposed to be for advanced students or young researchers, and may thus serve a useful purpose. One would have expected the authors of the second chapter to give advanced students details of their methodology rather than just a bald statoment of their results; and the authors of the third chapter are being a little bold in implying that in all recoptors a local potential chango spreads electrotonically into the afforent nerve ending.

But why print a kind of serial textbook at the rate of seven volumes a year-volumes whose content and quality is so uneven, and which at this level must date so rapidly? Many sciontific publishers now realize that now so many university and institutional libraries compulsively buy every purportedly esotoric book that comes off the presses, they have a captive clientèle and so presumably an assured profit. Just in case there should be any hesitation, or perhaps to lure tho unsuspecting potential individual purchasor, a title which, though misleading, is not quite downright mondacious is chosen, and it is left to tho eminent individual volume editor to explain it away as best he can in a preface whose brevity is evidence of his embarrassment. Were it not a spatial, didactic and financial waste, it would be amusing to contemplate Parkinson's law in tho particular case whereby the number of books published increases as the square of the number of libraries constrained to purchase them.

David Bowsher.

\section{POISON ON THE FARM}

\section{Garner's Veterinary Toxicology}

Third edition. Revised by L. (․ C. Clarke and Myra L. Clarke. Pp. 477. (London: Baillière, Tindall and Cassell, Ltd., 1967.) 60s. net.

Turs is an excollont reference work and fully maintains the tradition set by previous editions by Garner, and before that by Nicholson and by Lander. A comprehensive treatment of toxicology draws from the scientific disciplines of botany, chemistry, physiology, pathology and clinical medicine, and it might bo thought impossible to produce at once a textbook for the studont, a ready reference work for the practitioner, and an authoritativo text for the research worker. 'This has been achieved, however.

In the past fow decades there have been vast changes in the toxic hazards to which farm animals are exposed, for example, arsenic and copper compounds for the treatment of external and internal parasites have beon superseded by chlorinated hydrocarbon and organo-phosphorus compounds. The range of organic pesticides used in agriculture is entinually expanding, and it is to the authors' credit, thereforo, that the third edition of this volumo is only some 10 per cent larger than the previous edition, although one new section has been added and others have been revised and enlarged.

The book is divided into eight sections. The first part consists of a general thosis on toxicology including mode of action of poisons, diagnosis and treatment, and the remaining seven sections constitute an exhaustive catalogue of toxic materials encountered by farm animals. Each poison is dealt with under the general headings of "Occurrence", "Absorption", "Toxic Dose", "Symptoms", "Post-Mortem Lesions", "Diagnosis" and "Ireatment". The second part deals alphabetically with mineral or inorganic materials, and organic materials aro treated in the third, fourth and fifth parts, under the headings of "Drugs", "Pesticides" and "Miscellaneous Compounds". One of the co-authors, Papworth, has rowritten the section on posticides which contains very useful tables of chlorinated hydrocarbon and organophosphorus insocticidos listing both chemical and proprietary names. These latter are also included in the index, which greatly facilitates location in the text.

The sixth part of the book, which lists the toxic hazards of the plant kingdom, has been enlarged to include plants from other continents as well as Europe, and has been rearranged so that families appear in alphabetical order. The seventh part, on the dangers from radioactive materials, has been rewritten and enlarged by Garner, and the next part is the new addition containing short accounts of venomous stings and bites and doping of racing animals.

In all the topics covered, the literature has been reviewed up to 1964 or 1965 , and, with a few exceptions, all the important contributions have been included. Sclcction of materials has been judicious, as has been the omission of material of waning importance in modern agriculture.

As one of the very few works on veterinary toxicology in English this new edition will be welcomed by all who are concerned with diagnosis and treatment of poisoning in animals.

J. R. TODD

\section{FOOD MAY BE POISONOUS}

\section{Toxicants Occurring Naturally in Foods}

(A Monograph prepared by individual scientists of the Food Protection (committee.) (Publication No. 1354.) P'p. vii + 301 (Washington, D.C.: National Academy of Sciences, National Research Council, 1966.) \$6.00.

Mucr timo, money and argument is now being spent (and rightly so) in several countries to produce legislation regulating the safe levels of use for the synthetic chemical substances which are added deliberately to food for various aesthetic and technological purposes (for example, flavours, colours and preservatives) or which may occur as contaminants in food as the result of manufacturing processes, packaging or the use of pesticides in agriculture. As this book clearly shows, however, natural foodstuffs contain a large number of chemicals which are not nutrients, many of which could be toxic to man and animals if the foods in which they occur were eaten in sufficiont quantity. Poisoning as the result of cating natural foodstuffs may not be uncommon, for even the humble potato has caused many outbreaks of poisoning in man as a result of its content of the solanine alkaloids in certain circumstances. Thoso who would insist on eating natural foodstuffs without chemical fertilizers and posticides and without chemical additives aro, like most of us, not aware usually that poisonous substances or toxicants occur naturally in their food. As tho various chapters in this book show, foods contain naturally such substances as goitrogens, oestrogens, carcinogens, lathyrogens, haemagglutinins, stimulants, deprossants, allorgens, pressor amincs, antivitamins, antienzymes, 